\title{
Experiential Learning: Botanical Garden as a Place for Learning Plant Science
}

\author{
Noralizawati Mohamed, Noriah Othman \\ Centre of Landscape Architecture, Faculty of Architecture, Planning and Surveying, \\ Universiti Teknologi MARA, 42300 Puncak Alam, Selangor, Malaysia \\ leezmohd@yahoo.com
}

\begin{abstract}
Botanic garden is associated with environment conservation, outdoor recreation and education programme for students. The learning opportunities that take place in the garden functions as a window of knowledge, a platform to build better understanding beside aroused cognitive skills during visitation. This study is aimed to identify the potential of Putrajaya Botanical Garden as a learning environment. The finding showed the male respondents rated higher than the female in all attributes associated with experiential learning at the garden. With good practice of design and management, this garden can continuously serves as successful educational learning environment and achieve its mission.
\end{abstract}

Keywords: Experiential learning; leisure setting; botanic garden; educational learning environment

eISSN 2398-4279 @ 2018. The Authors. Published for AMER ABRA cE-Bs by e-International Publishing House, Ltd., UK. This is an open access article under the CC BY-NC-ND license (http://creativecommons.org/licenses/bync-nd/4.0/). Peer-review under responsibility of AMER (Association of Malaysian Environment-Behaviour Researchers), ABRA (Association of Behavioural Researchers on Asians) and cE-Bs (Centre for EnvironmentBehaviour Studies), Faculty of Architecture, Planning \& Surveying, Universiti Teknologi MARA, Malaysia.

DOI: https://doi.org/10.21834/ajqol.v3i12.142 


\subsection{Introduction}

Botanic garden is known as green space that associated with environment conservation, outdoor recreation and education programme for students. The learning opportunities that take place in the garden, functions as a window of knowledge, a platform to build better understanding, and aroused cognitive skills during visitation. Numbers of previous studies have agreed that the outdoor natural settings are one of the best examples that provide learning opportunity through experience and reflection (Hansen, 2012). A lot of research identified that the science education such as arboretums and plants identification can be upgrade to another higher level, where the garden is treated as students' centre of learning and outdoor laboratory (Hensen, 2012; Mehdi and Koorosh, 2015; Packer, 2004 \& Utama, 2015). This study presents the importance of conducting on-site experiential learning by linking students' learning preference and educational infrastructure in garden leisure setting. This study is aimed to identify the potential of Putrajaya Botanical Garden as a learning environment. The objectives of this study are (1) to determine the factors that encourage respondents to facilitate experiential learning and (2) to determine the respondents' satisfaction level based on the existing learning facilities.

\subsection{Literature Review}

\subsection{The Importance of Experiential Learning}

Experiential learning provides a holistic model of the learning process that gives added value to peoples' appreciation and knowledge improvement. And today, the practice of experiential learning is a global phenomenon and has significant impact in educating people especially in outdoor leisure setting. According to Packer (2004), this study is important to emphasize the central role of individual and society in many ways such as through play, leisure activities and visitation to museums, natural parks and gardens. Experts in attitude and behavior change advocate experiential learning as the most durable and effective strategy for producing citizens dedicated to environmental protection (Calkins, 2012), expend visitors understanding about nature (Hensen, 2012), learning flexibilities and problem- solving skills (Peterson, 2015), promotes critical thinking (Heinrich, 2015) and enhance self- esteem and boost motivations (Packer, 2004).

\subsection{Relationship of Experiential Learning Theory with Landscape Learning} Kolb explored the relationship of Experiential Learning Theory with landscape learning in 1984. He identified that this theory is a very important process where knowledge is created through concrete experience. This theory also found to be related to Theory of Flow by Csikszentmihalyi in 1990 where Flow can be experienced in any field of activity, for instance in sports, playing music, painting and leisure activities. Both theories have been used by many researcher and practitioners to value the quality of existing landscape in related with learning environment (Noriah et al., 2015; Hensen 2012; Peterson, 2015 and Heinrich, 2015). Their research approved that coherent landscape visuals, experiential education and effective instructional design could positively encourage experiential learning among users. 


\subsection{Garden Landscape Features and Motivation to Learn}

Recent studies have highlighted the importance of landscape features in different types of landscape setting such as at the open space and neighbourhood (Marlyana et al., 2012) parks and gardens (Noriah et al., 2015) and riverside area (Hilma and Mohammad, 2016). Their research summarized that the tangible and functional landscape features could encourage people to do outdoor recreational activities and feel satisfied. Noriah et al., 2015 previously addressed in their research that elements in the garden as one of the factors that contributed to visitation. In context of learning landscape, some studies investigated that the informational landscape features such as garden and interpretative signage give opportunity to educate the visitors and encourage the learning process (Hensen 2012; Ballantyne et al., 2008).

\subsection{Methodology}

\subsection{Background of Research Area}

Guided by the 'City in the Garden Concept', Putrajaya is planned to conserve and utilize its existing undulating contour for landscaped purpose- garden, lakes and parks (Putrajaya, 2016). The Putrajaya Botanical Garden is located at Precinct 1, Putrajaya and was opened to public on 2001. With more than 950 plant species around the world, this garden is well known as one of the biggest and successful botanical garden in Malaysia. The garden functions as both recreational spot and research centre for local people and tourist. The park is highly accessible via private or public transportation hence it is often used as a venue for environmental education programs, recreational activities, researches and as an ecotourism destination.

\subsection{Research Methodology}

Landscape architecture students from semester one and semester two recently participated in the survey of learning experience at Putrajaya Botanical Garden. There were 88 respondents and they were asked to answer the questions by referring to the garden's directory and follow the informational signage that provided for them. This approach was called as 'movement observation' by Peterson (2015) in his previous research. This study was administered by using a structured designed questionnaire. Following sections such as; respondents expectation before and after visiting the garden, things that encourage them to learn, respondents opinion for the garden as learning place were then discovered. They were also asked to rate the photographs showing different types of learning facilities at the final section using a five -point Likert scale where $1=$ very agree, $2=$ agree, $3=$ moderate, $4=$ disagree and, $5=$ very disagree.

\subsection{Results and Discussion}

\subsection{Respondents' Demographical Survey}


Table 1: Respondents' Demographical Background

\begin{tabular}{|c|l|c|c|}
\hline & & & \\
Variables & & Frequency & Percentage $\%$ \\
\hline Gender & Male & 22 & 25.0 \\
\hline & Female & 66 & 75.0 \\
\hline & Total & 88 & 100.0 \\
\hline Age & 20 years old and below & 57 & 64.8 \\
\hline & $21-30$ years old & 31 & 35.2 \\
\hline & Total & 88 & 100.0 \\
\hline Semester & 01 & 61 & 69.3 \\
\hline & 02 & 27 & 30.7 \\
\hline & Total & 88 & 100.0 \\
\hline
\end{tabular}

Source: Researchers (2016)

There were 88 respondents from first year Landscape Architecture Programme participated in this survey. According to Table $1,25.0 \%$ respondents were male while $75.0 \%$ were female. The result showed that $64.8 \%$ of them were 20 years and below and $35.2 \%$ were $21-30$ years old. Under the semester categories, students from Semester One represented 69.3\% while in Semester Two represented 30.7\%.

\subsection{Before Visitation (Respondents' Hopes from the Visit)}

Table 3: Respondents' Hopes from the Visit

\begin{tabular}{|c|l|c|c|c|c|}
\hline \multicolumn{1}{|c|}{ Variables } & Male & Female & F & Sig. \\
\hline 1 & To feel confident about myself & 4.36 & 4.05 & 0.065 & 0.094 \\
\hline $\begin{array}{l}\text { To get some ideas and use my } \\
\text { imagination }\end{array}$ & 4.45 & 3.94 & 0.035 & $\mathbf{0 . 0 0 7}^{\star *}$ \\
\hline 3 & To feel happy and satisfied & 4.50 & 4.18 & 0.479 & 0.072 \\
\hline 4 & To do things with my companion & 4.50 & 4.09 & 0.852 & $\mathbf{0 . 0 1 6 ^ { * }}$ \\
\hline 5 & To satisfy my mind curiosity & 3.91 & 4.02 & 0.023 & 0.584 \\
\hline 6 & To discover more about myself & 3.95 & 3.85 & 0.047 & 0.638 \\
\hline 7 & To socialize with others & 4.27 & 3.73 & 0.541 & $\mathbf{0 . 0 0 6 ^ { * * }}$ \\
\hline 8 & $\begin{array}{l}\text { To spend quality time with my family or } \\
\text { friends }\end{array}$ & 4.32 & 3.97 & 2.482 & 0.081 \\
\hline 9 & To alleviate boredom & 4.36 & 3.86 & 0.153 & $\mathbf{0 . 0 1 8 ^ { * }}$ \\
\hline 10 & To feel more confident about my abilities & 4.09 & 3.89 & 0.075 & 0.364 \\
\hline
\end{tabular}

Source: Researchers (2016)

$$
\text { Likert scale: }
$$

1 =Not important; 2 =Less important; 3= Moderate Important; 4=Important; 5= Very Important

*Significant different at $\mathrm{P}<0.05$

** Highly significant different at $\mathrm{P}<0.01$

Table 3 shows the respondents' hopes from the visit. The Cronbach's Alpha value for the above analysis is 0.95 . Result for highly significant different at $p<0.01$ is found for answers such as 'To socialize with others' with the male respondents rated higher (mean=4.27) and the female respondents rated lower (mean=3.73) and 'To get some ideas and use imagination' with the male respondents higher (mean=4.45) and the female respondents 
lower (mean=3.94). The significant different at $p<0.05$ is found for answers such as 'To do thing with my companion' which showed the male rating is higher (mean=4.50) than the female rating (mean=4.0). 'To alleviate boredom' showed that the male rating is higher (mean=4.36) and the female rating is lower (mean=3.86). The above mean results concluded that the male respondents scored higher than the female respondents although the number of male respondents is lesser than the female respondents. They also have certain expectations when do the visit thus making this visit is important to them.

\subsection{After Visitation (Respondents' Opinion on the Garden as Learning Place)}

Table 4: Respondents' Opinion on the Garden as Learning Place

\begin{tabular}{|c|l|c|c|c|c|}
\hline \multicolumn{1}{|c|}{ Variables } & Male & Female & F & Sig. \\
\hline 1 & It takes a lot of effort to learn things here & 4.50 & 4.17 & 0.692 & 0.066 \\
\hline 2 & $\begin{array}{l}\text { Understanding the information presented } \\
\text { here is important to me }\end{array}$ & 4.41 & 4.38 & 2.146 & 0.843 \\
\hline 3 & Learning here is a fun thing to do & 4.45 & 4.14 & 0.002 & 0.080 \\
\hline 4 & Learning here is difficult & 3.14 & 3.02 & 1.286 & 0.667 \\
\hline 5 & The visit or tour was for educational to me & 4.38 & 4.28 & 1.620 & 0.595 \\
\hline 6 & The visit or tour was for recreational to me & 4.33 & 4.30 & 0.387 & 0.830 \\
\hline
\end{tabular}

Source: Researchers (2016)

Likert scale:

1 =Not important; 2 =Less important; 3= Moderate Important; 4=Important; 5= Very Important

The Cronbach's Alpha value for this analysis is 0.7 . There is no significant differences were detected between the male and female respondents under Table 4. It can be concluded that the variables have similar rating values and not depending on the gender factors. However, the highest mean results for the above analysis shows that the male respondents preferred to 'Take a lot of Effort to Learn' with mean $=4.50$ while female respondents preferred to 'Understand the Information Presented' with mean=4.38. Both genders gave lowest rate for 'Learning here is Difficult'.

\subsection{Respondents' Opinion on the Botanic Garden as Place that Encourage Learning Experience}

Table 5: Factors that Encourage the Experiential Learning

\begin{tabular}{|c|l|c|c|c|c|}
\hline \multicolumn{1}{|c|}{ Variables } & Male & Female & F & Sig. \\
\hline 1 & The information/displays captured my interest & 4.18 & 4.14 & 0.609 & 0.818 \\
\hline 2 & $\begin{array}{l}\text { I became interested in things that didn't } \\
\text { previously interest me }\end{array}$ & 4.00 & 4.11 & 1.123 & 0.586 \\
\hline 3 & The information made me want to learn & 4.36 & 4.14 & 0.073 & 0.241 \\
\hline$\quad \begin{array}{l}\text { The information was presented in an } \\
\text { interesting way }\end{array}$ & 4.27 & 4.08 & 0.079 & 0.299 \\
\hline 5 & $\begin{array}{l}\text { I was reminded of something I already knew } \\
\text { or had experienced }\end{array}$ & 4.45 & 4.26 & 0.955 & 0.219 \\
\hline 6 & I had the opportunity to participate actively & 4.00 & 3.85 & 1.677 & 0.513 \\
\hline
\end{tabular}




\begin{tabular}{|c|l|c|c|c|c|}
\hline 7 & The information was surprising or unexpected & 4.18 & 3.82 & 0.158 & 0.059 \\
\hline 8 & The information was new to me & 4.23 & 3.94 & 0.260 & 0.106 \\
\hline$\quad$ & I was able to discuss the information with a & & & & \\
9 & new companion & 4.23 & 4.02 & 0.773 & 0.270 \\
\hline 10 & The information appealed to my emotions & 4.14 & 3.74 & 0.015 & $0.037^{*}$ \\
\hline 11 & The information appealed to my imagination & 4.33 & 3.94 & 2.479 & $0.022^{*}$ \\
\hline 12 & I had the opportunity to ask questions & 4.00 & 3.45 & 1.102 & $0.017^{*}$ \\
\hline & $\begin{array}{l}\text { I was able to see the real things or places the } \\
\text { information referred to }\end{array}$ & 4.41 & 4.08 & 0.298 & 0.070 \\
\hline
\end{tabular}

\section{Source: Researchers (2016)} Likert scale:

1 =Not important; 2 =Less important; 3= Moderate Important; 4=Important; 5= Very Important *Significant different at $P<0.05$

Table 5 represents the factors that encouraged the experiential learning activities and the Cronbach's Alpha value is 0.95 . The result shows significant different at $p<0.05$ for answers such as 'I had the opportunity to ask questions' with the male (mean=4.45) and female (mean=3.45), 'The information appealed to my imagination' with male (mean=4.33) and female (mean=3.94) and 'The information appealed to my emotions' with male (mean=4.14) and female (mean=3.74). The information provided at the garden encouraged imagination and emotion and increased curiosity about the plants. These results aligned with findings by other researchers that landscape preference is influenced by the observer's gender (de Souza Silva and Biondi, 2013). Aziz and Said (2012) carried out research on open green space. According to them, the physical factors of the space could give impact to social and emotional feeling of the users.

\subsection{Respondents' Opinion on Informational Signage and Educational Facilities}

Table 6: Respondents' Opinion on Importance of the Informational Signage and Educational Facilities

\begin{tabular}{|c|l|c|c|c|}
\hline \multicolumn{1}{|c|}{ Variables } & N & Mean & Rank \\
\hline 1 & The dry fruit and seed collection & 87 & 1.64 & 4 \\
\hline 2 & The plant specimen/herbarium & 86 & 1.63 & 3 \\
\hline 3 & Floor with leaves pattern and scientific name & 86 & 1.52 & 1 \\
\hline 4 & General information about the Botanic Garden & 84 & 1.73 & 8 \\
\hline 5 & Information board at the Dipterocarp walk & 84 & 1.79 & 9 \\
\hline 6 & Information on how to read the plant label for visitor & 84 & 1.79 & 9 \\
\hline 7 & Garden's directory & 84 & 1.67 & 5 \\
\hline 8 & Directional Signage around the garden & 86 & 1.76 & 6 \\
\hline 9 & Signage for plant category & 86 & 1.76 & 6 \\
\hline 10 & Plant tagging/labelling & 85 & 1.61 & 2 \\
\hline
\end{tabular}

Source: Researchers (2016)

Likert scale:

1 =Very agree; 2 =Agree; $3=$ Moderate; $4=$ Disagree; $5=$ Very Disagree

Based on the above results, the highest mean rating (mean=1.52) is the photo of 'Floor with leaves pattern and scientific name'. The students possibly rated highest this picture because it is located in front of the visitor information centre where it provides initial learning of the 
plant species before entering the garden. The second highest mean rating (mean=1.61) is the photo of 'Plant tagging/labelling'. This picture is found to give attraction to the students since tagging the plants assisted the respondents in associating the plant species with their botanical information. These findings aligned with previous research done by Noriah et al., (2015), Packer (2004) and Peterson (2015) where visitors preferred to garden setting that rich with information and user friendly. The third highest mean rating (mean=1.63) is the photo of 'Plant specimen/herbarium'. In studying the arboretums and plant sciences, the student should be exposed to an outdoor laboratory learning styles. According to Kolb (1984), knowledge should be created from a fundamental concrete. This is supported by Hansen (2012) where the students should learn on how to demonstrate their understanding by looking at the basic example before being able to extend their design thinking.

\subsection{Conclusion}

This study hopes to enrich users' learning experience in garden setting, and fill them with information. As stated under Chapter 36 of Agenda 21 (UNESCO, 1992), making environmental information also one of the strategies to increase public learning experience and it is also supported by the Botanic Garden Conservation International (1999). It is also aligned with research done by Abbas (2012) where the relationship between youth and environment is very important especially in developing countries for a better quality of life.

\section{Acknowledgement}

The research was funded by University of Technology MARA under the LESTARI research grant. High appreciation also expressed to the management of Putrajaya Botanical Garden for the valuable input into this study and granting us permission to conduct our research at the study area.

\section{References}

Abbas, M.Y. (2012). Children, Youth \& Environments (CYE): Lessons for Developing Countries? Procedia - Social and Behavioral Sciences, 38, $15-22$.

Aziz, N.F. \& Said, I. (2012). The Trends and Influential Factors of Children's Use of Outdoor Environments: A Review. Procedia -Social and Behavioral Sciences, 38, $204-212$.

Ballantyne, R., Packer, J. \& Hughes, K. (2008). Environmental Awareness, Interests and Motives of Botanic Garden Visitors: Implication for Interpretive Practice. Journal of Tourism Management, 29, 439-444.

Botanical Garden Conservation (1999), Retrieved from http://www. bgci.org

Calkins, M, (2012). The Sustainable Sites Handbook: A complete guide to the principles, Strategies and Practices fir Sustainable Landscape. NJ: John Wiley \& Sons. Inc. 
Chavez, M \& Sharrock, S (2013). The Role of Botanic Gardens in Building Capacity for Plant Conservation. Journal of Botanic Gardens Conservation International, 10 (1), 3-7.

de Souza Silva, R. R., \& Biondi, D. (2013). Assessment of Landscape Preference in the Botanical Garden of Curitiba, Paraná, Brazil. Revsbau, Piracicaba - SP, .8(1), 37-50.

Hensen, G. (2012). When Students Design Learning Landscapes: Designing for Experiential Learning through Experiential Learning. North American Colleges and Teachers of Agriculture Journal, 56, 30-35.

Heinrich, W.F., Habron, G.B, Johnson, H.L \& Goralnik, L. (2015). Critical Thinking Assessment across Four Sustainability-Related Experiential Learning Settings. Journal of Experiential Education, 38, 373-393.

Hilma, T.T. \& Mohammad, D.L. (2016). Planning for Riverside Area as Water Tourism Destination to Improve Quality of Life. Procedia - Social and Behavioral Sciences, 2344, 434-441.

Kolb. D.A. (1984). Experiential Learning as the Source of Learning and Development. Upper Saddle River, NJ: Prentice Hall

Marlyana Azyyati, M, Hafazah, A.K \& Mohd faez, L. (2012). Evaluating the Shah Alam City Council on the Hierarchy of Neighborhood Open Space. Procedia - Social and Behavioral Sciences, 36, 456-465.

Mehdi K., \& Koorosh, A. (2015). Achievement to Environmental Components of Educational Spaces for Iranian Trainable Children with Intellectual Disability. Procedia - Social and Behavioral Sciences, 201, 9-18.

Noriah, O., Noralizawati, M., Mohd Hisham, A. \& Mohd Ali Waliyuddin, A. R. (2015). Landscape Visual Studies in Urban Setting and Its Relationship in Motivational Theory. Procedia Social and Behavioral Science, 170, 442-451.

Noriah, O., Noralizawati, M., Mohd Hisham, A. \& Mohd Ali Waliyuddin, A. R. (2015). Exploring Human Oriented Design in Selected Botanical Gardens in Malaysia. Procedia Social and Behavioral Science, 201, 191-200.

Packer, J. (2004). Motivational Factors and the Experience of Learning in Educational Leisure Settings (Unpublished doctoral thesis). Queensland University of Technology, Australia

Parks of Putajaya (2016), Retrieved from http://www. ppj.gov.my

Peterson, Kay, DeCato, Lisa, Kolb \& David, A. (2015). Moving and Learning: Expending Style and Increasing Flexibility. Journal of Experiential Education, 38, 228-238.

United Nations Educational, Scientific and Cultural Organisation (UNESCO), Retrieved from http://ehc. unesco.org Utama, G.B.R (2015). Botanical Garden as a Recreational Park: Balancing Economic Interest with Conservation. International Journal of Scientific \& Engineering Research, 6, 148-158. 